\title{
Diagnosis of Metachromatic Leukodystrophy,
} Krabbe Disease, and Farber Disease after Uptake of Fatty Acid-labeled Cerebroside Sulfate into Cultured Skin Fibroblasts

\author{
Tooru Kudoh and David A. Wenger, Department of Pediatrics, University of \\ Colorado Health Sciences Center, Denver, Colorado 80262
}

A в S T R A C T $\left[{ }^{14} \mathrm{C}\right]$ Stearic acid-labeled cerebroside sulfate $(\mathrm{CS})$ was presented to cultured skin fibroblasts in the media. After endocytosis into control cells $86 \%$ was readily metabolized to galactosylceramide, ceramide, and stearic acid, which was reutilized in the synthesis of the major lipids found in cultured fibroblasts. Uptake and metabolism of the $\left[{ }^{14} \mathrm{C}\right] \mathrm{CS}$ into cells from typical and atypical patients and carriers of metachromatic leukodystrophy (MLD), Krabbe disease, and Farber disease were observed. Cells from patients with late infantile MLD could not metabolize the CS at all, while cells from an adult MLD patient and from a variant MLD patient could metabolize $\sim 40$ and $15 \%$, respectively, of the CS taken up. These results are in contrast to the in vitro results that demonstrated a severe deficiency of arylsulfatase $A$ in the late infantile and adult patient and a partial deficiency (21-27\% of controls) in the variant MLD patient. Patients with Krabbe disease could metabolize nearly $40 \%$ of the galactosylceramide produced in the lysosomes from the CS. This is in contrast to the near zero activity for galactosylceramidase measured in vitro. Carriers of Krabbe disease with galactosylceramidase activity near half normal in vitro and those with under $10 \%$ of normal activity were found to metabolize galactosylceramide in cells significantly slower than controls. This provides a method for differentiating affected patients from carriers with low enzyme activity in vitro. Cells from patients with Farber disease could catabolize only $\sim 15 \%$ of the ceramide produced from

This work was presented in abstract form in the Transactions of the American Society for Neurochemistry, Thirteenth Annual Meeting, March 1982.

Address reprint requests to Dr. Wenger.

Received for publication 25 January 1982 and in revised form 9 March 1982. galactosylceramide. This technique provides a method for the identification of typical and atypical patients and carriers of three genetic diseases using one substrate.

\section{INTRODUCTION}

Cerebroside sulfate $(\mathrm{CS})^{1}$ is a sphingolipid containing a sulfate moiety attached to carbon-3 of the galactosyl moiety that is attached in a beta linkage to ceramide $(\mathrm{N}$-acylsphingosine). Its catabolism proceeds via specific lysosomal enzymes that sequentially catalyze the hydrolysis of the sulfate moiety, the galactose moiety, and the fatty acid moiety. Inborn errors of lipid metabolism at each step in the breakdown result in specific lipid storage in certain tissues and unique clinical features. Metachromatic leukodystrophy (MLD) is a disease caused by a deficiency of CS sulfatase (arylsulfatase A) (1), Krabbe disease or globoid cell leukodystrophy is caused by a deficiency of galactosylceramide $\beta$-galactosidase (2) and Farber disease or lipogranulomatosis is caused by a deficiency of acid ceramidase activity (3). The deficiency of these enzymes has been demonstrated in leukocytes, cultured skin fibroblasts, and tissues, and this has permitted the reliable identification of most patients and carriers of these autosomal recessive diseases.

It recently has become apparent that measurements of lysosomal enzymes in vitro do not always give the correct genotype of the person who is being tested. The assays in vitro may require high concentration of bile salts or other additives to activate the enzyme in question. In recent years false positive or pseudode-

\footnotetext{
${ }^{1}$ Abbreviations used in this paper: CS, cerebroside sulfate; 4MU, 4-methylumbelliferyl; MLD, metachromatic leukodystrophy; NCS, nitrocatechol sulfate.
} 
ficient carriers (low enzyme activity in vitro in a healthy person) of MLD (4-9) and Krabbe disease (10) have been reported. These families present a problem when prenatal diagnosis for the disease in question is requested. This problem has been resolved for MLD through studies using suitably labeled $\left(\left[{ }^{35} \mathrm{~S}\right]\right.$ sulfate or $\left[{ }^{14} \mathrm{C}\right]$ stearic acid, labeled CS) in cultured skin fibroblasts and cultured amniotic cells $(8,9,11)$. In these experiments the labeled CS is presented to the cells in the media where it is taken up by endocytosis and subsequently metabolized in the lysosomes without the need for detergents or additives. This has resulted in the correct identification of fetuses with low in vitro activity in cultured amniotic cells and with either low turnover after uptake of $\left[{ }^{35} \mathrm{~S}\right] \mathrm{CS}(8)$ or near normal turnover after $\left[{ }^{14} \mathrm{C}\right]$ stearic acid-labeled CS (9). This has not yet been reported for families who have a healthy family member with low levels of galactosylceramide $\beta$-galactosidase. Shapiro et al. (12) described a patient with MLD who did not have the very low levels of CS sulfatase in vitro usually measured in patients with MLD. We must be able to clearly differentiate patients who have the disease in question (and perhaps delayed onset of symptoms) from healthy people who have enzyme levels near those of affected patients.

In this manuscript we describe the uptake and subsequent metabolism of $\left[{ }^{14} \mathrm{C}\right]$ stearic acid-labeled $\mathrm{CS}$ in cultured skin fibroblasts from controls and from typical and atypical patients and carriers of MLD, Krabbe disease, and Farber disease. The kinetics of uptake and the products of the reactions are characterized. The metabolism measured is compared to the enzyme levels found by in vitro techniques. This technique permits one to correctly identify typical and atypical patients and carriers of three lipidoses using one substrate, and to study the metabolism of many lipids in cultured human cells.

\section{METHODS}

Leukocytes and cultured skin fibroblasts. Leukocytes were isolated from heparinized venous blood by dextran sedimentation (13). Fibroblasts were grown from forearm skin biopsies using Eagle's Minimal Essential Media supplemented with $10 \%$ fetal calf serum, nonessential amino acids, Penstrep $(100 \mu \mathrm{g} / \mathrm{ml}$ streptomycin and $100 \mathrm{U} / \mathrm{ml}$ penicillin) and glutamine $(2 \mathrm{mM})$. The cell lines started in this laboratory from forearm skin biopsies include late infantile and adult MLD, Krabbe disease, typical and atypical carriers of Krabbe disease, GMl gangliosidosis, type 1, and controls. Cell lines from obligate carriers of late infantile MLD were supplied by Dr. H. Kihara (Mental Retardation Research Center Group, Pomona, CA), a cell line from a patient with atypical MLD (12) was supplied by Dr. M. M. Kaback, Harbor-UCLA Medical Center (Torrance, CA) and cell lines from patients and carriers of Farber disease were supplied by Dr. H. M. Moser (John F. Kennedy Institute, Baltimore, MD). Experiments using cell lines whose exact passage number was not known were limited to the first four passages in this laboratory. All samples were collected with informed consent.
Substrates. Nitrocatechol sulfate (NCS), 4-methylumbelliferyl-(4MU)- $\beta$-D-galactopyranoside and $4 \mathrm{MU}-\beta-N$-acetylglucosaminide were purchased from Sigma Chemical Co. (St. Louis, MO). $\left[1-{ }^{14} \mathrm{C}\right]$ stearic acid was purchased from New England Nuclear (Boston, MA). $\left[{ }^{14} \mathrm{C}\right]$ Stearic acid-labeled CS was prepared and characterized by the method described previously (9). ( $N$-stearoyl)galactosylceramide and lactosylceramide (Miles Laboratories, Elkhart, IN) were labeled in the galactose moieties using the galactose oxidase-sodium $\left[{ }^{3} \mathrm{H}\right]$ borohydride method described previously (14).

In vitro enzyme assays. The leukocyte and fibroblast pellets were homogenized in distilled water and used as the enzyme source without further purification. CS sulfatase activity was measured using NCS and $\left[{ }^{14} \mathrm{C}\right] \mathrm{CS}$ according to the method described previously (9). Beta-galactosidase activities toward $4 \mathrm{MU}-\beta$-D-galactopyranoside, galactosylceramide, and lactosylceramide were measured as previously reported (15). Total $\beta$-hexosaminidase activity was measured using $4 \mathrm{MU}-\beta-N$-acetylglucosaminide (15). In vitro enzyme activities are expressed as nanomoles of substrate hydrolyzed per milligram protein per hour at $37^{\circ} \mathrm{C}$.

$\left[{ }^{14} \mathrm{C}\right] \mathrm{CS}$ uptake experiments. The method previously used in this laboratory (9) was modified slightly. The appropriate amount of $\left[{ }^{14} \mathrm{C}\right] \mathrm{CS}(3,000-3,500 \mathrm{cpm} / \mathrm{nmol}$, radiopurity $99.6 \%)$ in chloroform-methanol (2-1, by vol) plus $5 \%$ of the volume of sterile distilled water was placed in a heat sterilized test tube, and the solvents were evaporated to near dryness with filtered nitrogen. The sterile, complete culture media was added to produce a final concentration of $15 \mathrm{nmol}$ of $\left[{ }^{14} \mathrm{C}\right] \mathrm{CS} / \mathrm{ml}$. The tube was vortexed and sonicated in a bath-type sonicator (Branson Instrument Co., Shelton, CT) five times for $2 \mathrm{~min}$ each time at $37^{\circ} \mathrm{C}$ to disperse the labeled lipid in the media. An aliquot was counted to insure complete dispersion of the lipid. The confluent cells in T-25 flasks were washed free of used media with sterile phosphate-buffered saline, and the cells then were given $4 \mathrm{ml}$ of the media containing the $\left[{ }^{14} \mathrm{C}\right] \mathrm{CS}$. In studies to measure the effect of $\left[{ }^{14} \mathrm{C}\right] \mathrm{CS}$ concentration on uptake, the cells were given 5,10 , 15 , or $20 \mathrm{nmol}$ of $\left[{ }^{14} \mathrm{C}\right] \mathrm{CS}$ per $\mathrm{ml}$ of media and harvested after $4 \mathrm{~d}$ on the cells. In other experiments the cells were given $15 \mathrm{nmol}$ of $\left[{ }^{14} \mathrm{C}\right] \mathrm{CS} / \mathrm{ml}$ and harvested after $1,2,3$, and $4 \mathrm{~d}$

On the day of harvest the media was removed and saved for extraction. The cells were washed well with phosphatebuffered saline and harvested by trypsinization. The cells obtained after centrifugation were washed again with phosphate-buffered saline, transferred to a small Duall homogenizer (Kontes Co., Vineland, NJ) and washed again. The pellet was homogenized in $0.1 \mathrm{ml}$ of distilled water and 0.003 $\mathrm{ml}$ was removed for a protein determination according to the method of Lowry et al. (16). The lipid was extracted with $0.5 \mathrm{ml}$ of chloroform-methanol $(2-1$, by vol) as described previously (9). The $\left[{ }^{14} \mathrm{C}\right] \mathrm{CS}$ taken up by the cells was calculated from the radioactivity in the lower phase after partition of the lipid extract. It is expressed as nanomoles per milligram protein per day.

Lipid metabolites in the extract were analyzed on silica gel thin-layer chromatography plates (Merck AG, Darmstadt, West Germany) developed in chloroform-methanolwater (70-30-5, by vol) and exposed to $\mathrm{x}$-ray film for $5 \mathrm{~d}$ as described previously (9). Each radioactive region on the plate was scraped and counted in $10 \mathrm{ml}$ of Bio-Solv HP (Beckman Instruments, Inc., Palo Alto, CA). Hydrolysis is expressed as a percentage distribution of metabolized products. CS sulfatase activity was calculated by dividing the radioactivity in the $C S$ region by the total radioactivity recovered from the plate. Galactosylceramide $\beta$-galactosidase 
activity was calculated similarly after subtracting the radioactivity in the $\left[{ }^{14} \mathrm{C}\right] \mathrm{CS}$ region from the total assuming that only $\left[{ }^{14} \mathrm{C}\right]$ galactosylceramide produced from $\left[{ }^{14} \mathrm{C}\right] \mathrm{CS}$ would be the starting substrate. Ceramidase activity was calculated after subtracting the radioactivity in the $\left[{ }^{14} \mathrm{C}\right] \mathrm{CS}$ and $\left[{ }^{14} \mathrm{C}\right]$ galactosylceramide regions from the total, assuming $\left[{ }^{14} \mathrm{C}\right]$ ceramide was the starting substrate.

Characterization of the radioactive metabolites. Radioactive regions from the thin-layer plate were eluted from the silica gel and cochromatographed with standard lipids as described previously (17). Simple lipids were purified using thin-layer plates of silica gel $\mathrm{H}(0.25 \mathrm{~mm}$ thick $)$ according to Skipski et al. (18). Phospholipids were separated according to the procedure described and eluted from the gel. Further purification of phospholipids was achieved by development on precoated silica gel plates in chloroformmethanol-water (70-30-5, by vol). Each area identified on the autoradiogram was eluted with a mixture of chloroformmethanol-water. The ratio was made to $10-5-3$ by vol and the lower phases were dried with nitrogen.

Methanolysis of glycerophospholipids was carried out by adding $1 \mathrm{ml}$ of $0.1 \mathrm{~N}$ sodium methoxide according to the method of Svennerholm (19). Sphingolipids and cholesterol ester were methanolyzed with $1 \mathrm{ml}$ of $5 \%$ (by weight) $\mathrm{HCl}$ in methanol in a sealed tube for $16 \mathrm{~h}$ at $80^{\circ} \mathrm{C}$. Fatty acid methyl esters were extracted with $1 \mathrm{ml}$ of hexane three times. The fatty acid methyl esters were analyzed by gas-liquid chromatography in a Hewlett-Packard 5710A apparatus (Hewlett-Packard Co., Palo Alto, CA) with a flame ionization detector and a radioactivity monitor. A $300-\mathrm{cm}$ glass column of $2 \mathrm{~mm}$ i.d., packed with 5\% OV-22 coated on 80-100 mesh Supelcoport (Supelco, Bellefonte, PA) was used. Fatty acid methyl ester standards were obtained from Sigma Chemical Co.

$\left[{ }^{3} \mathrm{H}\right]$ galactosylceramide uptake experiments. The media containing $5 \mathrm{nmol}\left[{ }^{3} \mathrm{H}\right]$ galactosylceramide $(18,000 \mathrm{cpm} /$ $\mathrm{nmol}$, radiopurity $93 \%) / \mathrm{ml}$ was prepared as described for the $\left[{ }^{14} \mathrm{C}\right] \mathrm{CS}$ uptake studies. After 2 and $4 \mathrm{~d}$ the media was removed and cells were harvested as described above. The lipids were extracted from the cells and $\sim 20,000 \mathrm{cpm}$ were spotted on a thin-layer silica gel plate, and developed in chloroform-methanol-water (70-30-5, by vol). The dried plate was sprayed with a surface autoradiography enhancer (En ${ }^{3}$ Hance spray, New England Nuclear) and exposed to $x-$ ray film. The area corresponding to galactosylsphingosine (prepared from galactosylceramide by alkali hydrolysis [20]) detected by exposure to iodine vapor was scraped and counted.

GM1 ganglioside $\beta$-galactosidase inhibition. To try to define the role of the different $\beta$-galactosidases in metabolizing the $\left[{ }^{14} \mathrm{C}\right]$ galactosylceramide produced from $\left[{ }^{14} \mathrm{C}\right] \mathrm{CS}$, a number of potential inhibitors of GMl $\beta$-galactosidase were added to the media before the addition of $\left[{ }^{14} \mathrm{C}\right] \mathrm{CS}$. These include GMl ganglioside $(0.075 \mathrm{mM}$ and $0.15 \mathrm{mM})$ prepared from mixed bovine brain gangliosides by the action of Clostridium perfringens neuraminidase, 1-thio- $\beta$-D-galactose (both from Sigma Chemical Co.) $(0.025 \mathrm{M}$ and $0.05 \mathrm{M}), \gamma-$ D-galactonolactone (Mann Research Laboratories, New York) $(0.025$ and $0.05 \mathrm{M})$ and para-nitrophenyl- $\beta$-D-galactopyranoside (Sigma Chemical Co.) $(2 \mathrm{mM})$.

The media containing the compound to be tested was passed through a membrane filter (Millex-GS, $0.22 \mu \mathrm{m}$, Millipore Corp., Bedford, MA) and added to the confluent flask of cells. After $3 \mathrm{~d}$ the in vitro lysosomal hydrolase activity was checked as described previously. GMl ganglioside was shown to be the best inhibitor of GMl $\beta$-galactosidase activity when assayed with $4 \mathrm{MU}-\beta$-D-galactopyranoside with- out causing changes in the other hydrolases and without changing the viability of the cells. After the cells reached confluency the media containing various concentrations of GMl ganglioside was replaced with $4 \mathrm{ml}$ of media containing $15 \mathrm{nmol}\left[{ }^{14} \mathrm{C}\right] \mathrm{CS} / \mathrm{ml}$. After $4 \mathrm{~d}$ the media and the cells were isolated, and the lipid was extracted as described above. Galactosylceramide metabolism in the treated cells was compared with the metabolism in cells not pretreated with GM1 ganglioside.

\section{RESULTS}

In vitro enzyme activities. The cultured skin fibroblasts (except those from the MLD families) were harvested and assayed for the lysosomal enzyme activities catalyzing the first two reactions in the degradation of CS plus lactosylceramide $\beta$-galactosidase I (also deficient in cells from patients with Krabbe disease) and $4 \mathrm{MU}-\beta$-galactosidase (deficient in cells from patients with GMl gangliosidosis). The results are summarized in Table I. Using both NCS and CS as substrates the cells from the patient with late infantile MLD had severely deficient arylsulfatase A activity. Obligate carriers had $\sim 50 \%$ of normal activity as expected. Cells from a patient with adult MLD had NCS and CS sulfatase activities $11 \%$ and $3.7 \%$ of controls, respectively. The cells from the patient with a variant form of MLD, possibly related to a deficiency of activator protein $(12,21)$, were found to have $27 \%$ of control activity using NCS and $21 \%$ of controls using CS as substrates.

Galactosylceramide and lactosylceramide $\beta$-galactosidase activities were severely deficient in cells from a patient with Krabbe disease. An obligate carrier was found to have $33-39 \%$ of control activities using these substrates. Two other healthy people were found to have very low activities using these two substrates in both leukocytes and cultured skin fibroblasts. One of these two was previously reported from this laboratory (10). There was no history of Krabbe disease in that family. The other was the father of a child with typical Krabbe disease. Using galactosylceramide both had values $<10 \%$ of controls. Their values were close to those measured in affected patients, and this demonstrated a potential problem in correctly identifying carriers in some families using only the in vitro assay. CS sulfatase and $4 \mathrm{MU}-\beta$-galactosidase activities in these pseudodeficient Krabbe carriers were within normal limits in both leukocytes (data not shown) and cultured skin fibroblasts.

In the cells from the patient and carriers of Farber disease the CS sulfatase, galactosylceramide $\beta$-galactosidase, and $4 \mathrm{MU}-\beta$-galactosidase activities were within the normal limits. Their acid ceramidase activity has been reported to be $<10 \%$ of controls in the patient and $\sim 50 \%$ of controls in the carriers (22). The cells from the patient with GMl gangliosidosis, type 
TABLE I

Lysosomal Enzyme Activities in Homogenates of Cultured Skin Fibroblasts

\begin{tabular}{|c|c|c|c|c|c|}
\hline \multirow[b]{2}{*}{ Fibroblast strain } & \multicolumn{5}{|c|}{ Substrates } \\
\hline & NCS• & CS & gal-cer & lac-cer & $4 \mathrm{MU}-\beta$-gal \\
\hline & \multicolumn{5}{|c|}{ nmol hydrolyzed/mg protein/h } \\
\hline \multicolumn{6}{|l|}{ MLD } \\
\hline Late infantile patient & 1.6 & 0 & ND & ND & 397 \\
\hline Adult patient & 47.6 & 2.5 & ND & ND & 450 \\
\hline Variant patient & 115 & 14.3 & ND & ND & 372 \\
\hline Late infantile carrier (1) $\downarrow$ & 171 & 19.0 & ND & ND & 374 \\
\hline Late infantile carrier (2) & 218 & 30.0 & ND & ND & 257 \\
\hline \multicolumn{6}{|l|}{ Krabbe disease } \\
\hline Infantile patient & 418 & 56.7 & 0.03 & 0.87 & 290 \\
\hline Typical carrier & 478 & 60.2 & 1.51 & 4.44 & 310 \\
\hline Pseudodeficient person & 411 & 50.8 & 0.16 & 2.44 & 221 \\
\hline Pseudodeficient carrier & 475 & 61.4 & 0.39 & 3.04 & 318 \\
\hline \multicolumn{6}{|l|}{ Farber disease } \\
\hline Infantile patient & 472 & 64.5 & 2.34 & 9.73 & 306 \\
\hline Typical carrier (1) & 461 & 58.7 & 1.72 & 11.2 & 397 \\
\hline Typical carrier (2) & $\mathbf{5 7 0}$ & 68.9 & 2.02 & 13.6 & 487 \\
\hline GM1 gangliosidosis, type 1 & & & & & \\
\hline Infantile patient & 462 & 65.2 & 1.58 & 9.66 & 3.10 \\
\hline \multicolumn{6}{|l|}{ Laboratory values } \\
\hline Controls $(n=60)$ Mean \pm SD & $430 \pm 174$ & $68.8 \pm 28.8 \S$ & $3.89 \pm 1.84$ & $13.4 \pm 5.3$ & $345 \pm 147$ \\
\hline
\end{tabular}

1 had only $1 \%$ of normal $4 \mathrm{MU}-\beta$-galactosidase activity, whereas the other enzymes checked were normal.

$\left[{ }^{14} \mathrm{C}\right] \mathrm{CS}$ uptake experiments and characterization of metabolites. The uptake of $\left[{ }^{14} \mathrm{C}\right] \mathrm{CS}$ by the cultured cells from controls and from patients was linear with the amount added in the media up to $20 \mathrm{nmol} / \mathrm{ml}$. The radioactivity in the lipid extract of the cells was followed daily for $4 \mathrm{~d}$ at a concentration of $15 \mathrm{nmol}$ of $\left[{ }^{14} \mathrm{C}\right] \mathrm{CS} / \mathrm{ml}$ media. The uptake of $\left[{ }^{14} \mathrm{C}\right] \mathrm{CS}$ in cell lines from controls, carriers, and patients ranged from 6.9 to $30.2 \mathrm{nmol} / \mathrm{mg}$ cell protein (mean 15.6) on day 1 , 11.1 to 41.7 (mean 23.4) on day $2,13.6$ to 47.7 (mean 27.8 ) on day 3 , and 17.4 to 49.0 (mean 31.2 ) on day 4. The amount of $\left[{ }^{14} \mathrm{C}\right] \mathrm{CS}$ taken up varied with cell growth, with slower growing cells having the lowest uptake.

The metabolic fate of the $\left[{ }^{14} \mathrm{C}\right] \mathrm{CS}$ taken up for $4 \mathrm{~d}$ was examined by thin-layer chromatography as shown on Fig. 1. In cells from controls only $13.5 \%$ of the $\left[{ }^{14} \mathrm{C}\right] \mathrm{CS}$ taken up was left unhydrolyzed and $86.5 \%$ was metabolized to other lipids on day 4 . In addition to galactosylceramide and ceramide, other radioactive spots corresponding to the major lipid components of cultured skin fibroblasts were found. They were identified as cholesterol ester, phosphatidylethanolamine, phosphatidylcholine, phosphatidylserine, phosphatidylinositol, sphingomyelin, and GM3 ganglioside. More than $95 \%$ of the radioactivity was found in their fatty acid moieties after methanolysis. This was identified as stearic acid by gas chromatography indicating reutilization of the stearic acid after hydrolysis from ceramide.

The rate of hydrolysis of $\left[{ }^{14} \mathrm{C}\right] \mathrm{CS}$ taken up is shown on Fig. 2A, B. In Fig. $2 A$ the rate of hydrolysis of $\left[{ }^{14} \mathrm{C}\right] \mathrm{CS}$ is shown with respect to time after feeding 15 $\mathrm{nmol} / \mathrm{ml}$ of media. On Fig. $2 \mathrm{~B}$ the hydrolysis of $\left[{ }^{14} \mathrm{C}\right] \mathrm{CS}$ is shown to approach maximal rates at $\sim 60 \mathrm{nmol} / 4$ $\mathrm{ml}$ in cells from controls. Using identical conditions, the cells from the patient with late infantile MLD did not show any appreciable metabolism of the $\left[{ }^{14} \mathrm{C}\right] \mathrm{CS}$ taken up. This is in contrast to the cell lines from the patient with adult MLD and from the patient with a variant type of MLD. The cells from the adult MLD patient could metabolize the $\left[{ }^{14} \mathrm{C}\right] \mathrm{CS}$ taken up at $\sim 40 \%$ 


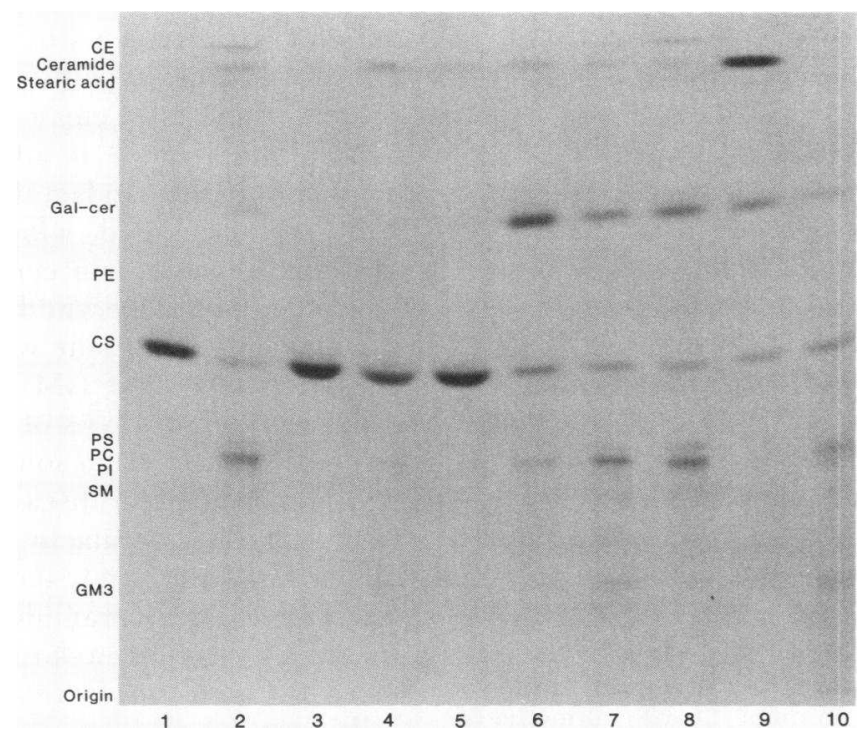

Figure 1 Autoradiogram of the lipids extracted from the cultured skin fibroblasts after the uptake of $\left[{ }^{14} \mathrm{C}\right] \mathrm{CS}$. The cells were given $15 \mathrm{nmol}\left[{ }^{14} \mathrm{C}\right] \mathrm{CS} / \mathrm{ml}$ of media, and the lipid was extracted after $4 \mathrm{~d}$ as described in Methods. Approximately 5,000 cpm were spotted, and after development in chloroform-methanol-water (70-30-5, by vol) the plate was exposed to $x$-ray film for $5 \mathrm{~d}$. Lane 1, starting $\left[{ }^{14} \mathrm{C}\right] \mathrm{CS}$; lane 2 , cells from a control; lane 3 , cells from a patient with late infantile MLD; lane 4, cells from a patient with adult MLD; lane 5, cells from the patient with variant type MLD; lane 6, cells from a patient with Krabbe disease; lane 7, cells from a typical carrier of Krabbe disease; lane 8, cells from a false positive carrier of Krabbe disease; lane 9, cells from a patient with Farber disease; lane 10, cells from a patient with GMl gangliosidosis, type 1. Abbreviations used: CE, cholesterol ester; gal-cer, galactosylceramide; PE, phosphatidylethanolamine; PS, phosphatidylserine; PC, phosphatidylcholine; PI, phosphatidylinositol; SM, sphingomyelin.

of the normal rate while the cells from the variant MLD patient could metabolize the $\left[{ }^{14} \mathrm{C}\right] \mathrm{CS}$ at about one-sixth the normal rate. The difference between the in vitro values (Table I) and the turnover within the cells can be appreciated. Cell lines from two obligate carriers of late infantile MLD could hydrolyze the $\left[{ }^{14} \mathrm{C}\right] \mathrm{CS}$ taken up within the normal range (not shown for clarity reasons).

Cell lines from patients and typical and atypical carriers of Krabbe disease were also given $\left[{ }^{14} \mathrm{C}\right] \mathrm{CS}$ under the identical conditions. $\left[{ }^{14} \mathrm{C}\right]$ Stearic acid-labeled galactosylceramide is produced in the lysosomes after the enzymatic hydrolysis of the sulfate moiety from the $\left[{ }^{14} \mathrm{C}\right] \mathrm{CS}$. In cell lines from controls only $8 \%$ of the $\left[{ }^{14} \mathrm{C}\right]$ galactosylceramide produced was unhydrolyzed by day 4 (Fig. 3A, B). The control range was narrow as related both to time in culture and to amounts given to the cells (Fig. 3A, B). Cells from a Krabbe disease patient could hydrolyze $42 \%$ of the $\left[{ }^{14} \mathrm{C}\right]$ galactosylceramide by day 4 . Although a complete study was done on only one cell line, this finding was also confirmed on two additional cell lines from patients with typical infantile Krabbe disease. This compares to the very low activity measured by the in vitro techniques. The typical obligate carrier and two false positive carriers metabolized the $\left[{ }^{14} \mathrm{C}\right]$ galactosylceramide in a range between the affected patient and controls (Fig. 3A, B). The difference was shown to be significant by the Student's $t$ test $(P=0.0002)$. In contrast, the cells from the patient with GMl gangliosidosis, type 1 were found to metabolize $\left[{ }^{14} \mathrm{C}\right]-$ galactosylceramide in the normal range (data not shown).

In cell lines from controls and from patients with Farber disease the $\left[{ }^{14} \mathrm{C}\right]$ galactosylceramide is further metabolized to $\left[{ }^{14} \mathrm{C}\right]$ stearic acid-labeled ceramide. A cell line from a patient with Farber disease was found to metabolize only $\sim 15 \%$ of the $\left[{ }^{14} \mathrm{C}\right]$ ceramide by day 4 (Fig. 4A, B). In contrast to the cells from a Farber patient, the cells from controls metabolized $>90 \%$ of the $\left[{ }^{14} \mathrm{C}\right]$ ceramide produced sequentially from the $\left[{ }^{14} \mathrm{C}\right] \mathrm{CS}$ given in the media. Two carriers of Farber disease were found to metabolize $\left[{ }^{14} \mathrm{C}\right]$ ceramide within the normal range (data not shown).

$\left[{ }^{3} \mathrm{H}\right]$ galactosylceramide uptake experiment and GM 1 $\beta$-galactosidase inhibition experiment. In an attempt to determine the mechanism for the significant level of metabolism of $\left[{ }^{14} \mathrm{C}\right]$ galactosylceramide in cells from 

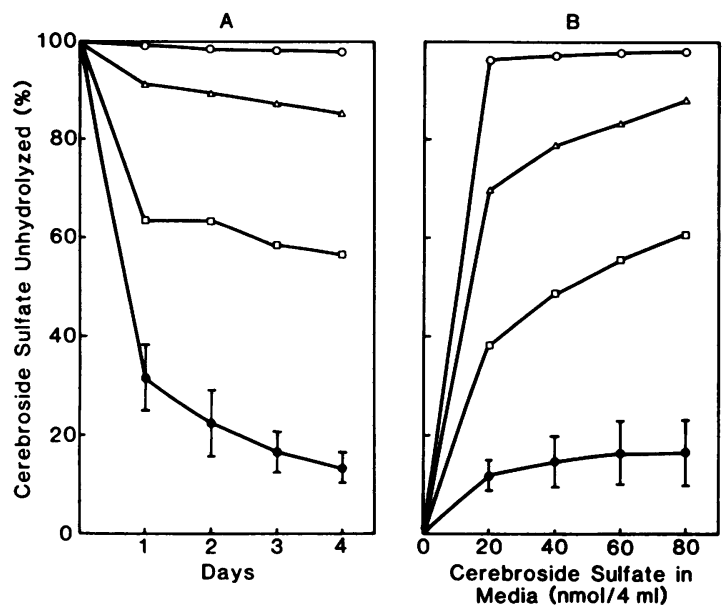

Figure 2 Percentage of unhydrolyzed CS in cells from controls and from patients with MLD with respect to days in culture after giving the cells $15 \mathrm{nmol}\left[{ }^{14} \mathrm{C}\right] \mathrm{CS} / \mathrm{ml}$ media (A) and to the concentration of $\left[{ }^{14} \mathrm{C}\right] \mathrm{CS}$ after $4 \mathrm{~d}$ of uptake (B) The cells were given the $\left[{ }^{14} \mathrm{C}\right] \mathrm{CS}$ in the media and harvested as described in Methods. The lipids were extracted and an aliquot was spotted on a thin-layer plate. Radioactive regions were located after autoradiography, scraped from the plate, and counted. Values from seven cell lines from controls (๑) are expressed as mean \pm SD. $O$, late infantile MLD; $\triangle$, variant form of MLD; $\square$, adult MLD.
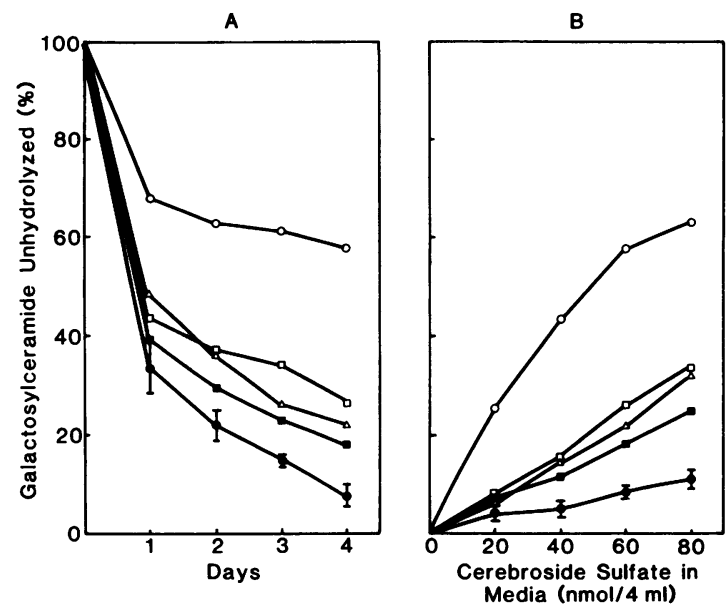

Figure 3 Percentage of unhydrolyzed galactosylceramide in cells from controls, and from a patient with Krabbe disease and from three carriers of Krabbe disease with respect to days in culture after giving the cells $15 \mathrm{nmol}\left[{ }^{14} \mathrm{C}\right] \mathrm{CS} / \mathrm{ml}$ media (A) and to the concentration of $\left[{ }^{14} \mathrm{C}\right] \mathrm{CS}$ after $4 \mathrm{~d}$ of uptake (B). The metabolism of galactosylceramide was determined by subtracting the counts per minute remaining in the CS region from the total counts per minute and dividing this into the counts per minute in the galactosylceramide region. Values from seven cell lines from controls (O) are expressed as mean $\pm \mathrm{SD}$. $O$, infantile Krabbe disease; $\Delta$, typical obligate carrier of Krabbe disease; $\square$, healthy person with low galactosylceramide $\beta$-galactosidase activity in vitro; $\boldsymbol{\square}$, obligate carrier of Krabbe disease with low galactosylceramide $\beta$-galactosidase activity in vitro. patients with Krabbe disease several hypotheses were examined. One hypothesis stated that there was an enzyme that could cleave the fatty acid from galactosylceramide once it accumulated to a significant level producing galactosylsphingosine (psychosine) and $\left[{ }^{14} \mathrm{C}\right]$ stearic acid, which could then be reutilized as if hydrolyzed from ceramide. By using galactoselabeled galactosylceramide we had the chance to see if galactosylsphingosine was produced. The other hypothesis stated that GMl $\beta$-galactosidase could also catalyze the hydrolysis of the galactosyl moiety from galactosylceramide to some degree, and this enzyme is active in Krabbe disease. By adding a specific inhibitor of GMl $\beta$-galactosidase or significant amounts of a preferred substrate the contribution of the enzyme toward galactosylceramide degradation could be minimized. Therefore, a larger proportion of unhydrolyzed $\left[{ }^{14} \mathrm{C}\right]$ galactosylceramide would be expected in cells from a Krabbe disease patient.

Uptake of $\left[{ }^{3} \mathrm{H}\right]$ galactosylceramide by cell lines from controls, from patients with Krabbe disease and from a patient with GMl gangliosidosis, type 1 was linear for $4 \mathrm{~d}$. The radioactivity in the upper aqueous phase after lipid extraction and partition was determined. This would contain $\left[{ }^{3} \mathrm{H}\right]$ galactose produced by enzymatic hydrolysis from $\left[{ }^{3} \mathrm{H}\right]$ galactosylceramide and a large portion of $\left[{ }^{3} \mathrm{H}\right]$ galactosylsphingosine produced if the fatty acid was hydrolyzed from the starting compound. The lower phase contained mainly the un-
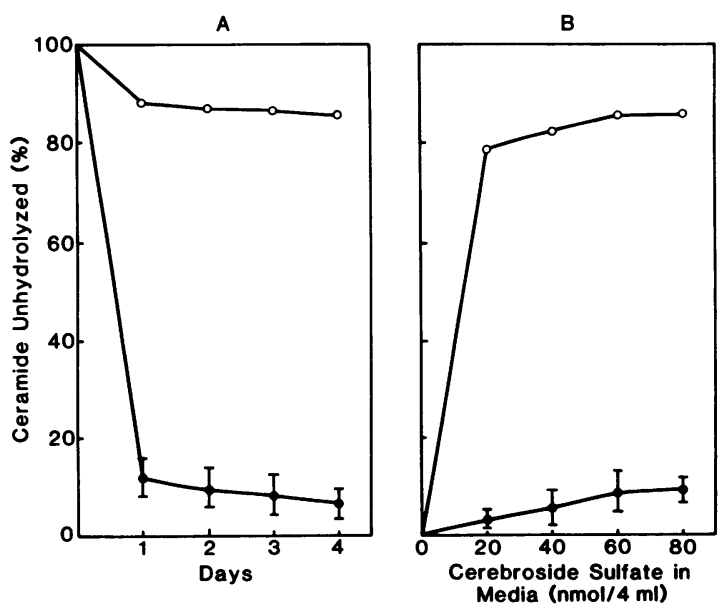

Figure 4 Percentage of unhydrolyzed ceramide in cells from controls and a patient with Farber disease with respect to days in culture after giving the cells $15 \mathrm{nmol}\left[{ }^{14} \mathrm{C}\right] \mathrm{CS} / \mathrm{ml}$ media (A) and to the concentration of $\left[{ }^{14} \mathrm{C}\right] \mathrm{CS}$ after $4 \mathrm{~d}$ of uptake (B). The metabolism of ceramide was determined by subtracting the counts per minute remaining in the CS and galactosylceramide regions from the total and dividing this into the counts per minute in the ceramide region. Values from seven cell lines from controls (O) are expressed as the mean \pm SD. $O$, Farber disease. 
metabolized [ $\left.{ }^{3} \mathrm{H}\right]$ galactosylceramide. The upper and lower phases were analyzed by thin-layer chromatography. There was no radioactivity at all in the region corresponding to galactosylsphingosine in extracts from controls, Krabbe disease, and GMl gangliosidosis after 2 and $4 \mathrm{~d}$ post-uptake. This may indicate that such a pathway does not exist in cultured skin fibroblasts.

GMl ganglioside was added in the media to cells for $3 \mathrm{~d}$ before its replacement by fresh media containing $\left[{ }^{14} \mathrm{C}\right] \mathrm{CS}$. The uptake of $\left[{ }^{14} \mathrm{C}\right] \mathrm{CS}$ was not affected by the GMl ganglioside up to $0.45 \mathrm{mM}$ in cell lines from controls and from patients with Krabbe disease. There was a small increase in the percentage of $\left[{ }^{14} \mathrm{C}\right]-$ galactosylceramide unhydrolyzed in all cell lines when the GM1 ganglioside concentration was $>0.075 \mathrm{mM}$. Even when the concentration of GMl ganglioside was raised to $0.45 \mathrm{mM}$ the cell lines from Krabbe disease patients still could hydrolyze $30-40 \%$ of the $\left[{ }^{14} \mathrm{C}\right.$ galactosylceramide produced from $\left[{ }^{14} \mathrm{C}\right] \mathrm{CS}$ (vs. $\sim 42 \%$ with no added GMl ganglioside, Fig. $3 \mathrm{~A}, \mathrm{~B}$ ). Although these experiments do not provide a satisfactory explanation for the significant metabolism of galactosylceramide in cell lines from patients with Krabbe disease, they do provide a basis for further experimentation.

\section{DISCUSSION}

The metabolism of $\left[{ }^{14} \mathrm{C}\right]$ stearic acid-labeled CS taken up by cultured skin fibroblasts from controls and from patients and carriers of certain lipid storage diseases is described. The substrate is of very high radiopurity (99.6\%) and is relatively simple to prepare according to a published procedure (23). Previous studies have demonstrated that CS could be incorporated into cultured skin fibroblasts, and that it could induce the formation of metachromatic inclusions in cells from MLD patients (24). Ultrastructural studies revealed that these inclusions consisted of undigested CS in the lysosomes which lacked CS sulfatase activity (1). These observations support the conclusion that the catabolism of CS in intact cells takes place in the lysosome, and that the use of $\left[{ }^{14} \mathrm{C}\right]$ stearic acid-labeled CS would be a useful substrate for the study of other lysosomal enzymes required for the complete catabolism of CS.

Uptake of $\left[{ }^{14} \mathrm{C}\right] \mathrm{CS}$ into cells varied between cell lines with fast growing lines having the greatest incorporation. Therefore, a percentage distribution of metabolites was used to quantitate the enzymatic metabolism of $\left[{ }^{14} \mathrm{C}\right] \mathrm{CS}$. In cell lines from controls the $\left[{ }^{14} \mathrm{C}\right] \mathrm{CS}$ is degraded to galactosylceramide, ceramide, and stearic acid, which then enters the fatty acid pool for the synthesis of the other major lipids found in cultured skin fibroblasts including phospholipids, gangliosides, and cholesterol ester
(Fig. 1). In cells from a patient with late infantile MLD practically no metabolism of the $\left[{ }^{14} \mathrm{C}\right] \mathrm{CS}$ was observed, which is in agreement with the in vitro findings (Table I). In cells from the patient with adult MLD the $\left[{ }^{14} \mathrm{C}\right] \mathrm{CS}$ could be metabolized at half the normal rate, which differs from the in vitro results, but provides an explanation for the later onset of the disease and the prolonged clinical course. When the cell line from the patient with the variant form of $\operatorname{MLD}(12,21)$ was given $\left[{ }^{14} \mathrm{C}\right] \mathrm{CS}$ there was only a small amount of metabolism, which differs from the in vitro results (Table I), but is consistent with the clinical picture. Obligate carriers of MLD metabolized the $\left[{ }^{14} \mathrm{C}\right] \mathrm{CS}$-like controls when it was presented to the cultured cells. These results in patients and carriers of MLD are in agreement with those of Kihara's group who used $\left[{ }^{35} \operatorname{S}\right] \mathrm{CS}(8,11,25)$ and our previous manuscript in which $\left[{ }^{14} \mathrm{C}\right] \mathrm{CS}$ was used under slightly different conditions (9).

A near complete block in the degradation of $\left[{ }^{14} \mathrm{C}\right.$ galactosylceramide was not observed in cell lines from patients with Krabbe disease (Fig. 1, 3A, B). This is in agreement with the results of Tanaka and Suzuki (26) who gave cells $\left[{ }^{3} \mathrm{H}\right]$ galactosylceramide directly. Our method provided $\left[{ }^{14} \mathrm{Clgalactosylceramide}\right.$ from $\left[{ }^{14} \mathrm{C}\right] \mathrm{CS}$ after enzymatic hydrolysis of the sulfate moiety in the lysosomes. About $40 \%$ of the galactosylceramide produced was further metabolized in cell lines from Krabbe patients by day 4 . This compares to $>90 \%$ in cell lines from controls. To explain the apparent discrepancy between the in vitro and in vivo enzymatic activities in Krabbe disease, two possible pathways were examined. The first possibility concerned the enzymatic removal of $\left[{ }^{14} \mathrm{C}\right]$ stearic acid moiety from the $\left[{ }^{14} \mathrm{C}\right]$ galactosylceramide to produce galactosylsphingosine. Patients with Krabbe disease are also deficient in galactosylsphingosine $\beta$-galactosidase activity (2), and this compound has been postulated to be the cause of the neuropathology observed (27). When we gave the cells $\left[{ }^{3} \mathrm{H}\right]$ galactosylceramide in the media no evidence for production of $\left[{ }^{3} \mathrm{H}\right]$ galactosylsphingosine could be found in extracts of cells from control or Krabbe disease.

Since GMl $\beta$-galactosidase activity is not deficient in cells from patients with Krabbe disease this enzyme could be responsible for the enzymatic hydrolysis of the galactosyl moiety from $\left[{ }^{14} \mathrm{Clgalactosylceramide}\right.$ in cells from patients with Krabbe disease. Under specific in vitro conditions purified GMl $\beta$-galactosidase can be demonstrated to catalyze this reaction at a low level $(28$, unpublished observations). If the GM1 $\beta$-galactosidase could be selectively inhibited or utilized totally for the hydrolysis of a preferred substrate, then cell lines from patients with Krabbe disease might hydrolyze less $\left[{ }^{14} \mathrm{Clgalactosylceramide.} \mathrm{Several} \mathrm{inhibitors} \mathrm{were} \mathrm{found} \mathrm{to}\right.$ be toxic to cultured cells or to inhibit both $\beta$-galactosidases and, therefore, were not useable. When GMl gan- 
glioside was used in experiments with Krabbe disease cell lines there still was significant metabolism of $\left[{ }^{14} \mathrm{C}\right]$ galactosylceramide. This could indicate either rapid utilization of the GMl ganglioside during the $4 \mathrm{~d}$ of the $\left[{ }^{14} \mathrm{C}\right] \mathrm{CS}$ feeding with retained ability to catalyze the galactosylceramide produced slowly from CS, or the presence of a third enzyme for the catabolism of galactosylceramide in cultured skin fibroblasts. Studies to explain this interesting finding are underway.

Carriers of Krabbe disease were found to have significantly less than the normal ability to catalyze the degradation of $\left[{ }^{14} \mathrm{C}\right.$ galactosylceramide produced from $\left[{ }^{14} \mathrm{C}\right] \mathrm{CS}$ (Fig. 1, 3A, B). This is in contrast to cell lines from carriers of MLD who metabolized CS-like controls and carriers of Farber disease who metabolized ceramidelike controls. This could indicate that galactosylceramide $\beta$-galactosidase is the rate limiting enzyme in the degradation of galactosylceramide in cultured skin fibroblasts. Typical carriers of Krabbe disease, with $30-60 \%$ of control galactosylceramide $\beta$-galactosidase activity in vitro, and false positive carriers of Krabbe disease with $8-15 \%$ of control activities were similar in their abilities to degrade galactosylceramide in cultured cells. This finding is critical to the correct identification of patients and carriers, and for the ability to differentiate such people during prenatal diagnosis. Recently, Christomanou et al. (29) reported a significant psychometric difference between carriers and noncarriers of Krabbe disease. They presented evidence that carriers with $<25 \%$ of control galactosylceramide $\beta$-galactosidase activity in vitro had significantly slower reaction times than normal. This finding may relate to our observations on the metabolism of galactosylceramide in intact cells.

Cultured skin fibroblasts from a patient with Farber disease could metabolize only $\sim 12 \%$ of the ceramide produced sequentially from CS, as compared to controls who could metabolize $>90 \%$ by day 4 (Fig. 1, 4A, B) These results differ significantly from those of Chen et al. (30). In their studies, cultured cells were given a higher concentration of $\left[{ }^{3} \mathrm{H}\right]$ oleic acid-labeled ceramide. They reported that $67 \%$ of the ceramide was further degraded in cells from controls and $37 \%$ in cells from Farber disease patients after $24 \mathrm{~h}$. The difference could reflect the nonlysosomal localization of some of the $\left[{ }^{3} \mathrm{H}\right]$ ceramide in their cells. An alkaline ceramidase has also been reported to be present in human skin fibroblasts (30). This is not deficient in patients with Farber disease. Since the $\left[{ }^{14} \mathrm{C}\right]$ ceramide produced in our experiments could only be produced by the sequential action of two lysosomal enzymes we feel we have a more specific measure of the acid ceramidase-deficient in Farber disease.

These studies illustrate the usefulness of this method for understanding lipid metabolism in cell lines from controls and from patients with typical and atypical forms of lysosomal storage diseases. With one labeled substrate three different genetic diseases can be diagnosed. Carriers with in vitro enzyme values near the range found in affected patients can be clearly identified, and accurate prenatal diagnosis can be accomplished in such families.

\section{ACKNOWLEDGMENTS}

The authurs are grateful to Drs. H. Kihara, H. W. Moser and M. M. Kaback for the fibroblast cultures they supplied. We also acknowledge the excellent technical assistance of Ms. Harriet McKelvey and Martha Sattler. We also thank Dr. S. I. Goodman for the use of the gas-liquid chromatography equipment.

This investigation was supported in part by grants from the National Institutes of Health (HD08315, NS10698, and HD10494). Dr. Wenger was supported in part by a Research Career Development Award (NS00108)

\section{REFERENCES}

1. Dulaney, J. T., and H. W. Moser. 1978. Sulfatide lipidosis: Metachromatic leukodystrophy. In The Metabolic Basis of Inherited Disease. J. B. Stanbury, J. B. Wyngaarden, and D. S. Fredrickson, editors. McGraw-Hill Book Co., Inc., New York. 4th edition. I: 770-809.

2. Suzuki, K., and Y. Suzuki. 1978. Galactosylceramide lipidosis: Globoid cell leukodystrophy (Krabbe's disease). In The Metabolic Basis of Inherited Disease. J. B. Stanbury, J. B. Wyngaarden, and D. S. Fredrickson, editors. McGraw-Hill Book Co., Inc., New York. 4th edition. I: 747-769.

3. Moser, H. W. 1978. Ceramidase deficiency: Farber's lipogranulomatosis. In The Metabolic Basis of Inherited Disease. J. B. Stanbury, J. B. Wyngaarden, and D. S Fredrickson, editors. McGraw-Hill Book Co., Inc., New York. 4th edition. I: 707-717.

4. Dubois, G., J. C. Turpin, and N. Baumann. 1975. Absence of ASA activity in healthy father of a patient with metachromatic leukodystrophy. N. Engl. J. Med. 293: 302.

5. Dubois, G., K. Harzer, and N. Baumann. 1977. Very low arylsulfatase $A$ and cerebroside sulfatase activities in leukocytes of healthy members of metachromatic leukodystrophy family. Am. J. Hum. Genet. 29: 191-194.

6. Lott, I. T., J. T. Dulaney, A. Milunsky, D. Hoefnagel and H. W. Moser. 1976. Apparent biochemical homozygosity in two obligatory heterozygotes for metachromatic leukodystrophy. J. Pediatr. 89: 438-440.

7. Butterworth, J., D. M. Broadhead, and A. J. Keay. 1978. Low arylsulfatase A activity in a family without metachromatic leukodystrophy. Clin. Genet. 14: 213-218.

8. Kihara, H., C-K. Ho, A. L. Fluharty, K. K. Tsay, and P. L. Hartlage. 1980. Prenatal diagnosis of metachromatic leukodystrophy in a family with pseudo arylsulfatase A deficiency by the cerebroside sulfate loading test. Pediatr. Res. 14: 224-227.

9. Kudoh, T., M. Sattler, J. Malmstrom, M. A. Bitter, and D. A. Wenger. 1981. Metabolism of fatty acid-labeled cerebroside sulfate in cultured cells from controls and metachromatic leukodystrophy patients. J. Lab. Clin. Med. 98: 704-714

10. Wenger, D. A., and V. M. Riccardi. 1976. Possible misdiagnosis of Krabbe disease. J. Pediatr. 88: 76-79.

11. Fluharty, A. L., R. L. Stevens, and H. Kihara. 1978. Cerebroside sulfate hydrolysis by fibroblasts from a par- 
ent with metachromatic leukodystrophy. J. Pediatr. 92: 782-784.

12. Shapiro, L. J., K. A. Aleck, M. M. Kaback, H. Itabashi, R. J. Desnick, N. Brand, R. L. Stevens, A. L. Fluharty, and H. Kihara. 1979. Metachromatic leukodystrophy without arylsulfatase A deficiency. Pediatr. Res. 13: 1179-1181.

13. Skoog, W. A., and W. S. Beck. 1956. Studies on the fibrinogen, dextran and phytohemagglutinin methods of isolating leukocytes. Blood. 11: 436-454.

14. Radin, N. S., L. Hof, R. M. Bradley, and R. O. Brady. 1969. Lactosylceramide galactosidase-comparison with other sphingolipid hydrolases in developing rat brain. Brain Res. 14: 497-505.

15. Wenger, D. A., M. Sattler, C. Clark, H. Tanaka, K. Suzuki, and G. Dawson. 1975. Lactosyl ceramidosis: normal activity for two lactosyl ceramide $\beta$-galactosidases. Science (Wash., D. C.). 188: 1310-1312.

16. Lowry, O. H., N. J. Rosebrough, A. L. Farr, and R. Randall. 1951. Protein measurement with Folin phenol reagent. J. Biol. Chem. 193: 265-275.

17. Skipski, V. P., J. J. Good, M. Barclay, and R. B. Reggio. 1968. Quantitative analysis of simple lipid classes by thin-layer chromatography. Biochim. Biophys. Acta. 152: 10-19.

18. Skipski, V. P., R. F. Peterson, and M. Barclay. 1964. Quantitative analysis of phospholipids by thin-layer chromatography. Biochem. J. 90: 374-378.

19. Svennerholm, L. 1968. Distribution and fatty acid composition of phosphoglycerides in normal human brain. J. Lipid Res. 9: 570-579.

20. Erickson, J. S., and N. S. Radin. 1973. N-Hexyl-O-glucosyl sphingosine, an inhibitor of glucosyl ceramide $\beta$ glucosidase. J. Lipid Res. 14: 133-137.

21. Stevens, R. L., A. L. Fluharty, H. Kihara, M. M. Kaback, L. J. Shapiro, B. Marsh, K. Sandhoff, and G. Fischer. 1981. Cerebroside sulfatase activator deficiency induced Metachromatic leukodystrophy. Am. J. Hum. Genet. 33: 900-906.
22. Dulaney, J. T., A. Milunsky, J. B. Sidbury, N. Hobolth, and H. W. Moser. 1976. Diagnosis of lipogranulomatosis (Farber disease) by use of cultured fibroblasts. J. Pediatr. 89: 59-61.

23. Dubois, G., B. Zalc, F. LeSaux, and N. Baumann. 1980. Stearoyl $\left[1-{ }^{14} \mathrm{C}\right]$ sulfogalactosylsphingosine $\left(\left[{ }^{14} \mathrm{C}\right]\right.$ sulfatide) as substrate for cerebroside sulfatase assay. Anal. Biochem. 102: 313-317.

24. Porter, M. T., A. L. Fluharty, S. E. Harris, and H. Kihara. 1970. The accumulation of cerebroside sulfates by fibroblasts in culture from patients with late infantile metachromatic leukodystrophy. Arch. Biochem. Biophys. 138: 646-652.

25. Porter, M. T., A. L. Fluharty, J. Trammell, and H. Kihara. 1971. A correlation of intracellular cerebroside sulfatase activity in fibroblasts with latency in metachromatic leukodystrophy. Biochem. Biophys. Res. Commun. 44: 660-666.

26. Tanaka, H., and K. Suzuki. 1978. Globoid cell leukodystrophy (Krabbe's disease). Metabolic studies with cultured fibroblasts. J. Neurol. Sci. 38: 409-419.

27. Svennerholm, L., M.-T. Vanier, and J.-E. Mansson. 1980. Krabbe disease: a galactosylsphingosine (psychosine) lipidosis. J. Lipid Res. 21: 53-64.

28. Suzuki, K., H. Tanaka, T. Yamanaka, and O. V. Damme. 1980. The specificity of $\beta$-galactosidase in the degradation of gangliosides. In Structure and Function of Gangliosides. L. Svennerholm, H. Dreyfus and P.-F. Urban, editors. Plenum Publishing Corp., New York. I: 307-318.

29. Christomanou, H., S. Jaffe, J. Martinius, C. Cap, and K. Betke. 1981. Biochemical, genetic, psychometric, and neuropsychological studies in heterozygotes of a family with globoid cell leukodystrophy (Krabbe's disease). Hum. Genet. 58: 179-183.

30. Chen, W. W., A. B. Moser, and H. W. Moser. 1981. Role of lysosomal acid ceramidase in the metabolism of ceramide in human skin fibroblasts. Arch. Biochem. Biophys. 208: 444-455. 